\title{
Astrochronology for the Messinian Sorbas basin (SE Spain) and orbital (precessional) forcing for evaporite cyclicity
}

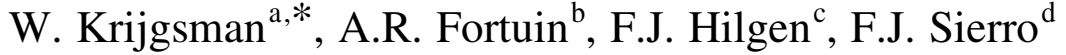

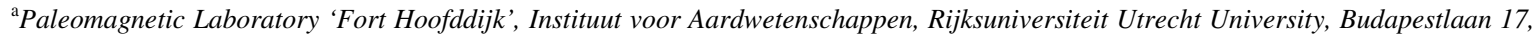 \\ 3584 CD Utrecht, Netherlands \\ ${ }^{\mathrm{b}}$ Faculty of Earth Sciences, Vrije Universiteit, De Boelelaan 1085, 1081HV, Amsterdam, Netherlands \\ ${ }^{c}$ Department of Geology, Institute of Earth Sciences, Utrecht University, Budapestlaan 4, 3584 CD Utrecht, Netherlands \\ ${ }^{\mathrm{d} D e p a r t m e n t ~ o f ~ G e o l o g y, ~ U n i v e r s i t y ~ o f ~ S a l a m a n c a, ~} 37008$ Salamanca, Spain
}

Received 25 November 1998

\begin{abstract}
The Sorbas basin of SE Spain contains one of the most complete sedimentary successions of the Mediterranean reflecting the increasing salinity during the Messinian salinity crisis. A detailed cyclostratigraphic study of these successions allows a correlation of the sedimentary cycle patterns to astronomical target curves. Here, we present an astrochronological framework for the Messinian of the central part of the Sorbas basin. This framework will form a solid basis for high-resolution correlations to the marginal carbonate facies and to the Central Mediterranean area.

The early Messinian Abad Member contains 55 precession induced sedimentary cycles marked by homogeneous marl-opalrich bed alternations in the 'Lower Abad' and by homogeneous marl-sapropel alternations in the 'Upper Abad'. Astronomical tuning results in an age of $5.96 \mathrm{Ma}$ for the transition to the Yesares evaporites and thus for the onset of the 'Messinian salinity crisis'. The marl-sapropel cycles of the 'Upper Abad' are replaced by gypsum-sapropel cycles (14) in the Yesares Member, indicating that the evaporite cyclicity is related to precession controlled oscillations in (circum) Mediterranean climate as well. As a consequence, gypsum beds correspond to precession maxima (insolation minima) and relatively dry climate, sapropelitic marls to precession minima (insolation maxima) and relatively wet climate. An alternative (glacio-eustatic) obliquity control for evaporite cyclicity can be excluded because the number of sedimentary cycles with a reversed polarity is too high.

Sedimentation during the Abad, Yesares, and the overlying coastal sequences of the Sorbas Member, took place in a continuously marine environment, indicating that marine conditions in the Sorbas basin prevailed at least until 5.60-5.54 Ma. According to our scenario, deposition of the Yesares and Sorbas Member took place synchronously with deposition of the 'Lower Evaporites' in the Central Mediterranean. Finally, the continental Zorreras Member consists of 8 sedimentary cycles of alternating reddish silts (dry climate) and yellowish sands (wet climate) which correlates very well with the 'Upper Evaporites' and Lago Mare facies of the Mediterranean. (c) 2001 Elsevier Science B.V. All rights reserved.
\end{abstract}

Keywords: Messinian; Mediterranean; Stratigraphy; Evaporites; Orbital forcing

\section{Introduction}

* Corresponding author. Tel.: +31-30-253-5246; fax: +31-30253-1677.

E-mail address: krijgsma@geo.uu.nl (W. Krijgsman).

In the early 1970s, shipboard scientists of the Deep Sea Drilling Project, Leg 13, discovered the existence of giant evaporite bodies of Messinian age under the 


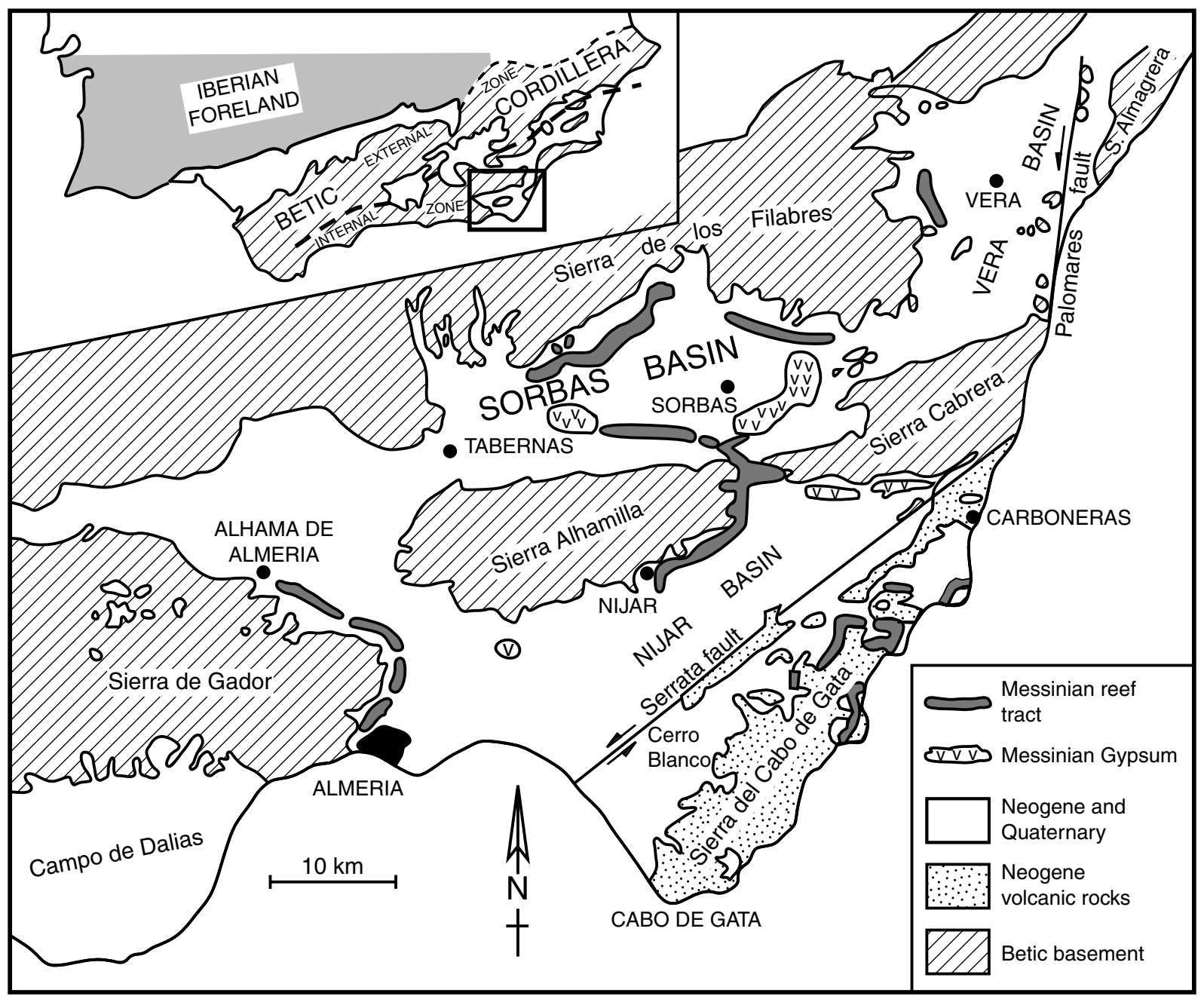

Fig. 1. Tectonic sketch map of the Sorbas basin and surrounding areas. Indicated are the distributions of the outcropping marginal Messinian reefs (Cantera Member) and gypsum (Yesares Member).

deep-sea floor of the Mediterranean basin. These findings amplified the hypothesis of a 'Mediterranean Messinian salinity crisis' (Selli, 1960), which is regarded as one of the most catastrophic events of Neogene history (Hsü et al., 1973; Ryan et al., 1973; Cita et al., 1978). According to the original models (Hsü et al., 1973, 1977), the Mediterranean became progressively restricted and finally completely isolated from the Atlantic Ocean, favouring deposition of gypsum, halite and evaporitic limestone in a deep-desiccated basin. Ever since its discovery, however, the Messinian salinity crisis (MSC) has been a subject of debate (Drooger, 1973). Major controversies concerned the timing (synchronous vs diachronous), origin (glacio-eustatic vs tectonic), environmental conditions (deep vs shallow water) and impact (global vs regional). A final solution for these controversies was long obstructed by the absence of an accurate and reliable time frame for the Messinian. The application of biostratigraphy is strongly hampered by an unfavourable hypersaline environment, magnetostratigraphy is difficult because of less-suitable lithologies (diatomites and evaporites), and radioisotopic dating is limited due to the 


\section{MEDITERRANEAN}

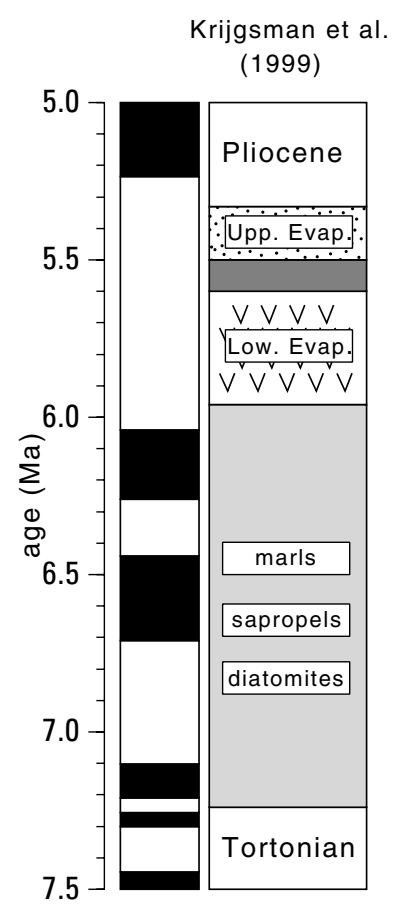

SORBAS BASIN
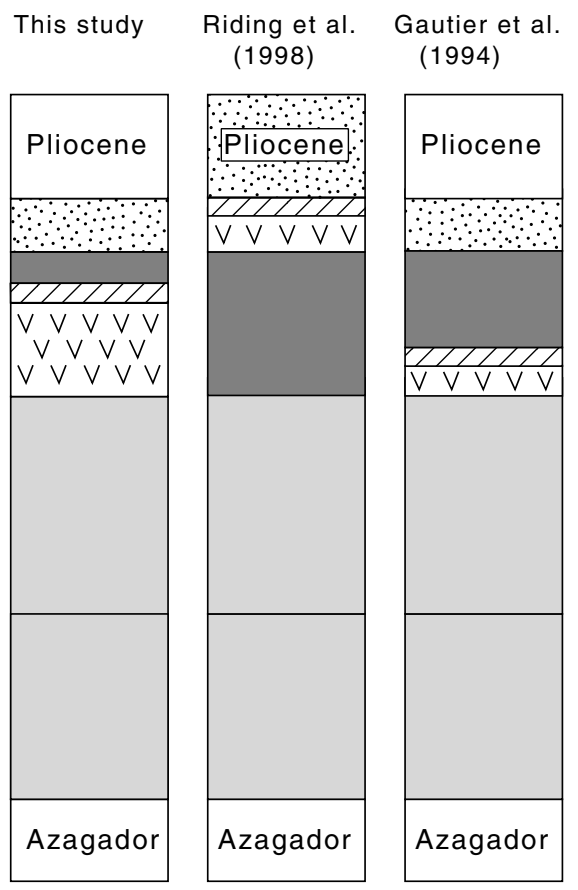

\begin{tabular}{c} 
(1991) \\
\hline
\end{tabular}

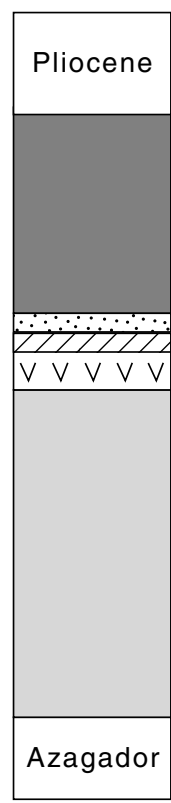

Müller \& Hsü (1986)

Dronkert

(1985)

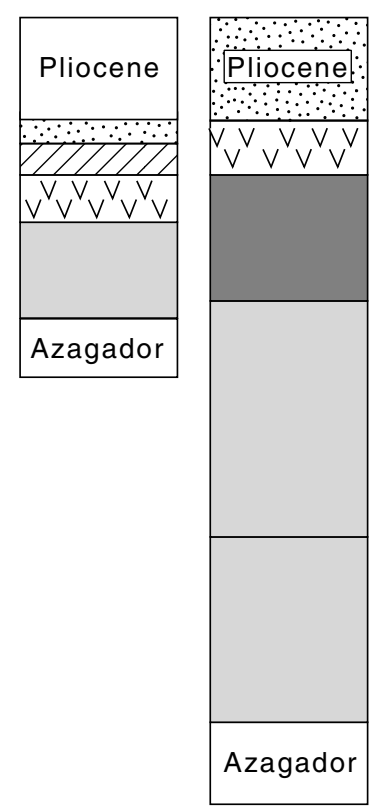
Sorbas

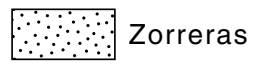

hiatus

Fig. 2. Schematic overview of different chronostratigraphic models for the Sorbas basin showing the large controversies in timing and duration of the various stratigraphic members. All models including the polarity column are updated to the recently established Messinian astrochronology (Krijgsman et al., 1999a). The models of Dronkert (1985) and Riding et al. (1998) are based on a correlation of the Yesares Member to the 'Upper Evaporites' of the Mediterranean. The models of Müller and Hsü (1987) and Gautier et al. (1994), and of this paper, correlate the Yesares Member to the 'Lower Evaporites' and the Zorreras to the 'Upper Evaporites'. The differences in duration between our model and that of Gautier et al. (1994), lies in the precessional origin for the sedimentary cyclicity. Note that precessional control also excludes the other age models.

rare intercalations of datable ash layers. Furthermore, stratigraphic studies are restricted to land-based sections because the evaporites of the deep Mediterranean basins have not been drilled to their base.

One of the most complete land-based Messinian sequences, reflecting the increasing salinity of the Mediterranean during the MSC, is situated in the Sorbas basin of SE Spain (Fig. 1). The Messinian deposits of the Sorbas basin are excellently exposed and play an important role in numerous MSC-models (Dronkert, 1976, 1985; Pagnier, 1976; Ott d'Estevou, 1980; Rouchy, 1982; Gautier et al., 1994; Clauzon et al., 1996; Riding et al., 1998; Rosell et al., 1998). A thick and continuous sequence of marls and evapor- ites was deposited in the central parts of the Sorbas basin (Iaccarino et al., 1975; Troelstra et al., 1980; Sierro et al., 1993, 1997, 1999) while its margins were covered by extensive carbonate platforms and reef complexes (Ott d'Estevou, 1980; Martín and Braga, 1994; Braga and Martín, 1996). Direct relationships between the evaporites and the carbonate complexes, however, are not well established because of the lack of reliable age constraints and the lateral discontinuity of exposures.

Magnetostratigraphic and biostratigraphic results on the pre-evaporitic marls provided the first reliable dating of the onset of evaporite deposition in the Sorbas basin (Gautier et al., 1994; Sierro et al., 
1999; Krijgsman et al., 1999a). However, these techniques are not useful to date intra-MSC sequences, because these sequences are confined to a single (reversed) magnetic chron (C3r; Gautier et al., 1994) and lack age diagnostic planktic foraminifera. As a consequence, different and controversial age models for the Messinian Sorbas basin came into existence, while also the correlation to marginal areas and the Central Mediterranean remained equivocal (Fig. 2).

All stratigraphic members of the Sorbas basin, however, display a distinct sedimentary cyclicity. The cyclicity in the pre-evaporites consists of an alternation of homogeneous marls and laminated organic rich layers, termed sapropels, and is unambiguously shown to be related to the orbital cycle of precession (Sierro et al., 1997, 1999; Krijgsman et al., 1999a), having an average periodicity of $21 \mathrm{kyr}$. The markedly cyclic alternation of gypsum beds and sapropellike sediments in the evaporite unit (Dronkert, 1985) suggests that these gypsum cycles are astronomically controlled as well, and hence that they are potentially suitable for astronomical dating purposes. In addition, also the post-evaporitic deposits show a distinct sedimentary cyclicity (Ott d'Estevou, 1980; Roep et al., 1998).

In this paper, we present the magnetostratigraphy and cyclostratigraphy of the Messinian sediments of the Sorbas basin by carefully determining the total number of sedimentary cycles in each lithostratigraphic unit. Correlation to the astronomical curves will result in reliable age constraints for the sedimentary sequence of the Sorbas basin and will allow a detailed correlation of the different units and events to the Messinian sequences elsewhere in the Mediterranean, for which recently an astrochronology has been developed (Krijgsman et al., 1999a).

\section{Stratigraphic framework and previous models}

The Sorbas basin is one out of a series of pull-apart basins, formed along the NE-SW trending eastern Betic shearzone (Fig. 1; Montenat et al., 1987) and related to ongoing approach of African and Betic continental crust. These basins are surrounded by often highly elevated basement blocks, consisting of various types of metasediments. The basic Neogene stratigraphy for the marine deposits of the Sorbas and adjacent basins was established by Völk and Rondeel (1964), while the first detailed geological map with a description of the Miocene stratigraphy was presented by Ruegg (1964). The oldest Neogene sediments are conglomerates of Serravallian age which are overlain by Tortonian turbiditic sandstones. Strike-slip faulting in late Tortonian times (Stapel et al., 1996) resulted in a major unconformity, separating the turbidite-rich succession from onlapping shallow marine calcarenites known as the Azagador Member (uppermost Tortonian). Across the Tortonian/Messinian (T/M) boundary and in response to tectonic activity the Sorbas basin rapidly subsided, which provided accumulation space for the deposition of a complete Messinian succession.

The upper Miocene of the Sorbas basin is generally subdivided in two formations: the Turre Formation and the Caños Formation (Völk and Rondeel, 1964; Ruegg, 1964). These units are again subdivided in six subsequent members: (1) shallow marine calcarenites (Azagador Member) of latest Tortonian age; (2) earliest Messinian upper bathyal marls ('Lower Abad Member') with fauna indicative of normal, well-oxygenated open-marine waters; (3) restricted and shallower but still open marine marls ('Upper Abad Member') alternating with sapropels and diatomites in the central part of the basin; (4) evaporites (Yesares Member) predominantly consisting of selenitic gypsum alternating with pelitic laminites; (5) interbedded sandy and laminitic deposits (Sorbas Member) developed as prograding coastal sequences; and (6) continental deposits (Zorreras Member) consisting of reddish silts with intercalations of lacustrine limestones containing a so-called caspibrackish fauna.

Most chronostratigraphic models on the Sorbas basin agree on the correlation of the Azagador/Abad transition to the interval straddling the T/M boundary (Fig. 2). This correlation is confirmed by magnetostratigraphy and by the first regular occurrence (FRO) of the Globorotalia miotumida group at the very base of the Abad marls (Troelstra et al., 1980; Sierro et al., 1993, 1999; Gautier et al., 1994). The 'Lower/Upper Abad' transition is dated to occur at the base of chron C3An.2n, the Abad/Yesares transition (the onset of the MSC) at the base of chron C3r (Gautier et al., 1994; Krijgsman et al., 1999a).

Major controversies, however, still exist on the 
chronostratigraphic position of the Yesares, Sorbas and Zorreras Members (Fig. 2). Most authors assume the Yesares evaporites to be (partly) time-equivalent to the 'Lower Evaporites' of Sicily and the Central Mediterranean basins (Müller and Hsü, 1987; Gautier et al., 1994; Clauzon et al., 1996). A different model is proposed by Dronkert (1985), Martín and Braga (1994) and Riding et al. (1998), assuming a hiatus in the Sorbas basin at the Abad/Yesares transition (to be discussed in Section 5.2) and a correlation of the Yesares evaporites to a post-MSC reflooding of the Mediterranean. The latter scenario requires a correlation of the Yesares Member to the 'Upper Evaporites'/Lago Mare units and the Zorreras Member to the Pliocene (Dronkert, 1985; Cunningham et al., 1994; Riding et al., 1998). In contrast, the Zorreras Member is correlated to the latest Messinian, based on the observation of caspibrackish ostracod fauna with a strontium signal equivalent to the Lago Mare ostracods (latest Messinian) of the other Mediterranean basins (Müller and Hsü, 1987; Gautier et al., 1994; Roep et al., 1998).

\section{Integrated stratigraphy}

High-resolution magnetostratigraphic studies can only discriminate between the correlation of the Zorreras Member to the Pliocene (if the normal Thvera chron could be recorded) or to the late Messinian (only reversed polarities). For the different correlations of the Yesares Member, only cyclostratigraphic (or radioisotopic) data can resolve the existing controversies. For this reason, we sampled for magnetostratigraphic purposes the type section of the Zorreras Member in detail (21 levels), while the Yesares and Sorbas Member were sampled in less detail (8 levels). All samples were measured on a $2 \mathrm{G}$ DC cryogenic magnetometer and were thermally demagnetised until the level of reproducible results. Furthermore, we focused our study on the well-developed sedimentary cyclicity of all stratigraphic units to obtain the total number of cycles for each stratigraphic member and to establish a correlation with the astronomical curves.

\subsection{Abad member}

Time control on the early Messinian Abad Member of the Sorbas basin has considerably been improved by magnetostratigraphic, biostratigraphic and cyclostratigraphic dating (Gautier et al., 1994; Sierro et al., 1999; Krijgsman et al., 1999a). The Azagador/Abad transition straddles the Tortonian/Messinian boundary (7.24 Ma; Hilgen et al., 1995), as the first regular occurrence of the Globorotalia miotumida group is observed in the lowermost non-cyclic part of the section. Other important bioevents are the FO of Globorotalia nicolae and the sinistral to dextral coiling change of Neogloboquadrina acostaensis, which occur in the upper part of chron C3Ar (6.83 Ma; Hilgen et al., 1995; Krijgsman et al., 1997a) and in the middle part of chron C3An.1r (6.34 Ma; Hilgen and Krijgsman, 1999; Sierro et al., 2001), respectively.

The Abad marls show a distinct sedimentary cyclicity, primarily controlled by the astronomical cycle of precession (Sierro et al., 1999; Vazquez et al., 2000). The dominance of a precession-related signal suggests that regional climatic oscillations are principally responsible for the faunal fluctuations and sedimentary cyclicity. The basal part of the 'Lower Abad' consists of homogeneous silty marls. Cyclicity becomes clearly visible several metres higher and is characterised by the occurrence of indurated (Opal CT-rich) layers rhythmically intercalated within the homogeneous marls. The sedimentary cyclicity is also expressed in the gamma ray signal, which shows minima in the indurated layers and maxima in the homogeneous marls (Steehouwer and Van der Moolen, 1996). A number of 21 indurated layers is present until the transition to 'Upper Abad' marls, which is generally characterised by a hiatus or by an interval characterised by (syn)sedimentary deformation (slumping) probably caused by increased tectonic instability of the basin margins (for more details see Sierro et al., 1997, 1999).

The 'Upper Abad' shows the same type of cyclicity as the 'Lower Abad', but laminated brownish organic rich layers (sapropels) occur in the middle part of the homogeneous marls. During sapropel deposition, high planktonic foraminiferal diversities are indicative of relatively normal stable marine conditions, while during homogeneous marl deposition low diversities seem to indicate the presence of anomalous surface water conditions, with seasonally driven, highly fluctuating salinities (Sierro et al., 1997, 1999). The total 

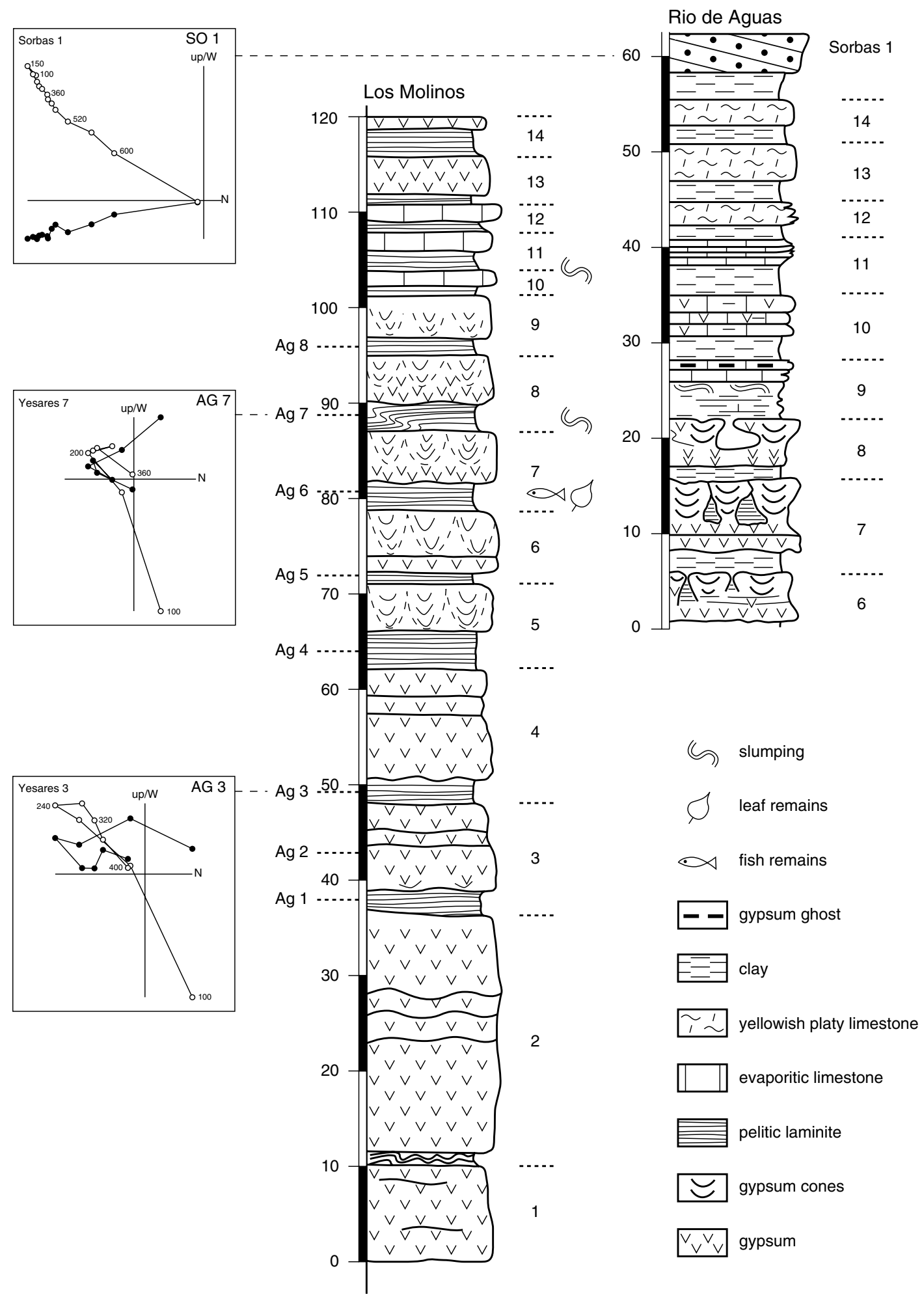
number of precession related cycles in the 'Upper Abad' is 34 till the transitional interval to the Yesares evaporites. Based on these high-resolution biostratigraphy and cyclostratigraphy, a bed-to-bed correlation can be made to the neighbouring Nijar basin (Fig. 1), which contains exactly the same number of sedimentary cycles in the Abad Member as the Sorbas basin (Sierro et al., 1999).

\subsection{Yesares member}

Magnetostratigraphic dating revealed that the Abad/ Yesares transition took place in the lower part of magnetic chron C3r (Gautier et al., 1994; Krijgsman et al., 1999a) and that the entire Yesares Member has been deposited during an interval of reversed polarity (Fig. 3). The Abad sections of the Gypsum Quarry and Los Perales show that the Abad/Yesares transition is a non-erosive sedimentary contact with the first gypsum bed conformably overlying Abad cycle C55 (Sierro et al., 2001). The basal part of the Yesares Member is well exposed in the Los Molinos section (Dronkert, 1985), located in the central part of the Sorbas basin (Fig. 3). This section starts in the gypsum canyon north of the village of Los Molinos de Rio Aguas and can be followed to the north because of a moderate $\mathrm{N}$ dip of the strata. The transition to the Sorbas Member is best exposed south of Sorbas village in the Rio de Aguas bridge section (Dronkert, 1985) and in the adjacent cliffs to the north of the river bed (60 m exposed, partly overlapping the Los Molinos section).

The sedimentary cyclicity in the Yesares evaporites is generally developed as alternations of evaporites and calcareous pelitic laminites. The evaporites mainly consist of selenite crystals with different types of crystal arrangements (Dronkert, 1985), but in some outcrops also alabastrine gypsum (chickenwire structure) is present at the base of the gypsum sequence. The lowermost evaporite beds are the thickest and mainly consist of massive selenite. Higher in the sequence, bottom upward growth of gypsum crystals forming conical clusters (nucleation cones) is also observed (Fig. 3). Towards the upper part of the Yesares Member, the evaporite beds become progressively less well developed, and are replaced by yellowish laminated carbonates which locally contain gypsum ghosts. These carbonates alternate with brownish to greyish marly interbeds. The sedimentary cyclicity in this interval no longer consists of distinctly different lithotypes. Consequently, the cyclic pattern is less well exposed, although the colour changes remain conspicuous.

The sedimentary cyclicity in the Yesares Member has earlier been described by Dronkert (1976), as 12 cycles of alternating gypsiferous and carbonate-pelitic laminated sediments. However, his stratigraphic log of the Los Molinos section shows 13 cycles (Dronkert, 1985). Also Rosell et al. (1998) recognised 13 gypsum layers in the Los Molinos section, but an unusually thick interval between their cycles 9 and 10 suggests that one gypsum layer is lacking. We thoroughly re-investigated the cyclicity in the Yesares Member and recognised fourteen sedimentary cycles (Fig. 3), as also indicated in the section figured by Ott d'Estevou and Montenat (1990); their Fig. 8). The difference with the earlier studies lies in the interpretation of the highly problematic uppermost part of the Los Molinos section. This part of the Yesares Member is better exposed in the Rio de Aguas section, where the sands of the lowermost Sorbas sequence are exposed as well (Roep et al., 1998). Correlation of the two sections is possible through the presence of three gypsum beds with well developed cones in the Rio de Aguas section, which are the lateral equivalent of evaporite cycles 6-8 in the Los Molinos section (see also Dronkert, 1985).

According to Dronkert (1985), the evaporite-pelite cycles represent deposition in a subaqueous environment under varying hypersaline conditions. Mixing with less saline water in combination with the presence of dwarfed marine microfauna in the pelitic intervals indicates restricted connections to inflowing ocean waters. There are no wave ripples, or waveinduced current ripples (only ripple sets of turbidites) and no signs of mudcracks, soils, raindrops or animal

Fig. 3. Cyclostratigraphy and Zijderveld diagrams of the Yesares Member. The composite lithological column of the Los Molinos and the Rio de Aguas sections consists of 14 sedimentary cycles of alternating gypsum beds or evaporitic limestones with pelitic laminites or clays. The correlation between the two sections is established by the presence of three beds with well-developed gypsum cones in the Rio de Aguas section which are the lateral equivalents of evaporites 6-8 in the Los Molinos section (see also Dronkert, 1985). In the Zijderveld diagrams, the closed (open) symbols represent the projection of the vector end-points on the horizontal (vertical) plane; values represent temperatures in ${ }^{\circ} \mathrm{C}$. 


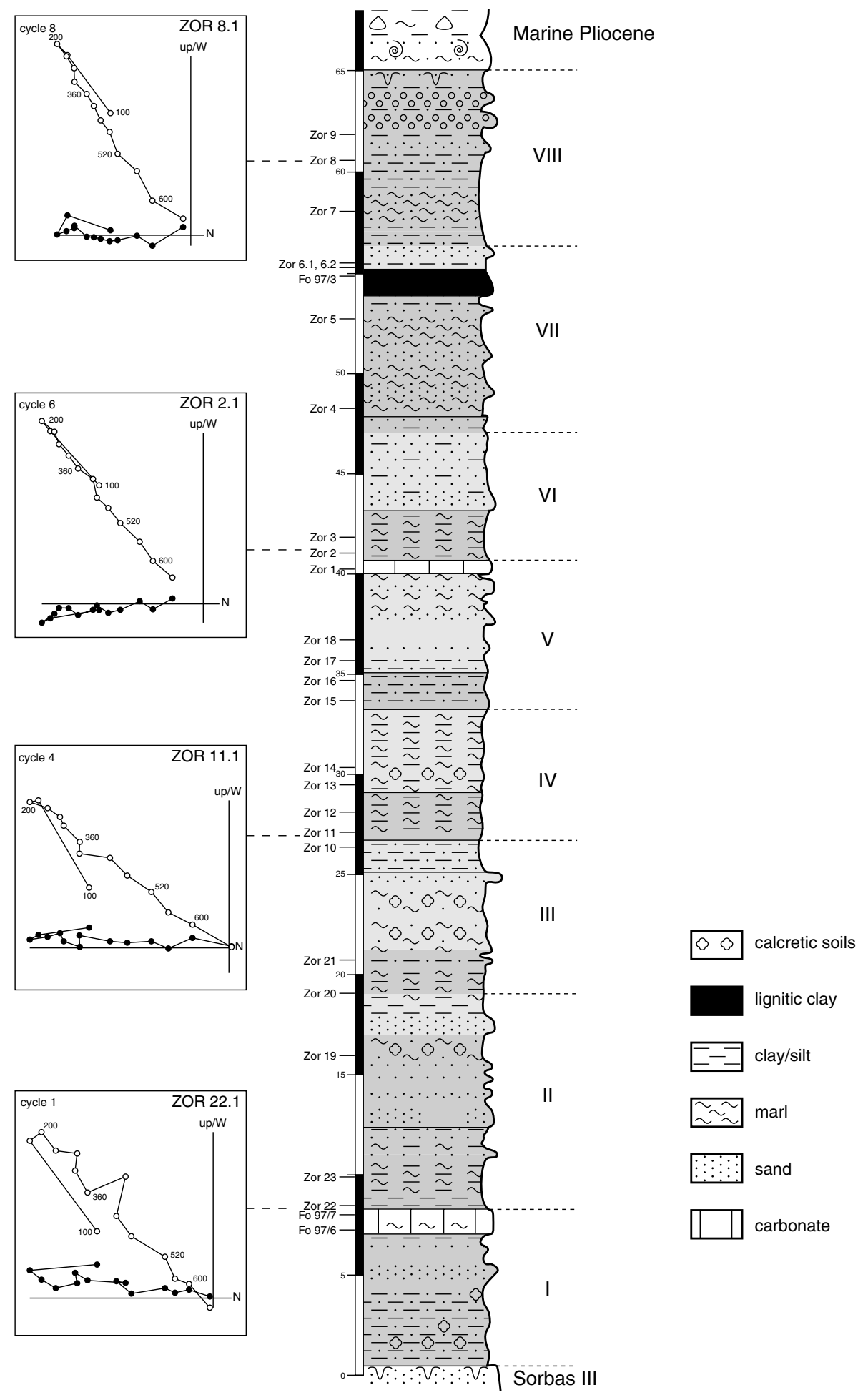


tracks, while burrowing is very limited. Typical sabkha sequences of nodular gypsum associated with enterolithical structures do not occur. Development of algal stromatolites is not observed.

\subsection{Sorbas member}

The Sorbas Member is, like the Yesares Member, entirely of reversed polarity, correlative to chron C3r. It overlies the evaporites in the centre of the basin, and onlaps the reef cores and their clinoforms in marginal areas (Roep et al., 1998). The Yesares/Sorbas transition reflects an upward shallowing trend when coastal environments were established in large parts of the Sorbas basin. Dabrio and Polo (1995) suggest that the Sorbas Member represents the lateral equivalent of a facies association known as the Terminal Carbonate Complex (TCC, Esteban and Giner, 1977; Esteban, 1979). This TCC includes Porites patch reefs and thrombolites (Dabrio et al., 1985; Martín et al., 1993). During deposition of the Sorbas Member, the basin was a narrow embayment open to the east and southeast, as uplift of the Sierra Cabrera occurred later (Roep et al., 1998).

The Sorbas Member constitutes a stack of three depositional sequences consisting of coastal sandstone bodies, separated by shelf muds (Roep et al., 1998). Each sequence shows upward coarsening, shallowing and eastward progradation. Laminated clays and marls occur at the base representing the offshore facies. Upward, micaceous sands, sandy calcarenites, and conglomerates follow, indicative of an offlapping beach-barrier environment (Roep et al., 1979). Superimposed on the three coastal sequences, a higher-frequency cyclicity is observed, related to small-scale sea-level oscillations (Roep et al., 1998). A total of ten of these higher-frequency cycles have been recognised in both the Sorbas Member and the TCC (Dabrio and Polo, 1995; Roep et al., 1998). We refer to Roep et al. (1998) for a more detailed sedimentological description of the Sorbas Member.

\subsection{Zorreras member}

Our paleomagnetic results from the Zorreras type section reveal that the entire member is of reversed polarity (Fig. 4) correlative to chron C3r. The type section of the Zorreras Member is situated in the central part of the Sorbas basin, $1.5 \mathrm{~km} \mathrm{NE}$ of Sorbas, in the present quarry of the Zorreras hill. Here, the Zorreras Member overlies burrowed sandstones of the uppermost sequence of the Sorbas Member. The Sorbas/Zorreras transition is abrupt but clearly not erosional, since in most places the youngest of the three Sorbas coarsening upward sequences is found below the first Zorreras strata. Detailed mapping showed that the base of the Zorreras onlaps the Sorbas Member in the area of Sorbas town (Ten Veen, 1991; Offringa, 1991).

The Zorreras Member (Ruegg, 1964) is characterised by an alternation of dominantly reddish silts and more yellowish-grey to pink sandy marls. Most lithoclastics have been derived from Nevado-Filabride basement units, as exposed to the north. Sandy intercalations are common; the relative amount of sand and coarser clastics increases northward (Ruegg, 1964). The numerous levels of calcareous caliche nodules in the fines reflect a continental depositional environment (Ott d'Estevou, 1980). Highly characteristic, the member includes two interbeds of white lagoonal limestone containing a socalled caspibrackish Lago Mare fauna (Hydrobia, and the brackish water ostracod Cyprideis undosa, Van Harten, 1980; small shells and Chara oogonia) indicating a latest Messinian age (Roep and Beets, 1977; Roep and Van Harten, 1979; Ott d'Estevou, 1980; Van de Poel, 1994). This characteristic biofacies is widespread in the entire Mediterranean province during the latest Messinian (Cita et al., 1990). The Zorreras Member ends with 2-3 m of yellow, fossiliferous calcarenite with a gravelly lag deposit at the base. This sandstone is rich in molluscs and brachipods indicative of a Pliocene Age (Roep et al., 1979; Ott d'Estevou, 1980). The fact that this top, which not only deviates in lithology but also in age,

Fig. 4. Cyclostratigraphy and Zijderveld diagrams of the Zorreras Member. The lithological column shows eight sedimentary cycles of alternating reddish silts (dark shaded) and yellowish sandy marls (light shaded). Two conspicuous levels of white lagoonal limestones (in cycles I and V) represent relatively wet periods during which the Sorbas basin was flooded by brackish waters. In the Zijderveld diagrams, the closed (open) symbols represent the projection of the vector end-points on the horizontal (vertical plane; values represent temperatures in ${ }^{\circ} \mathrm{C}$. 

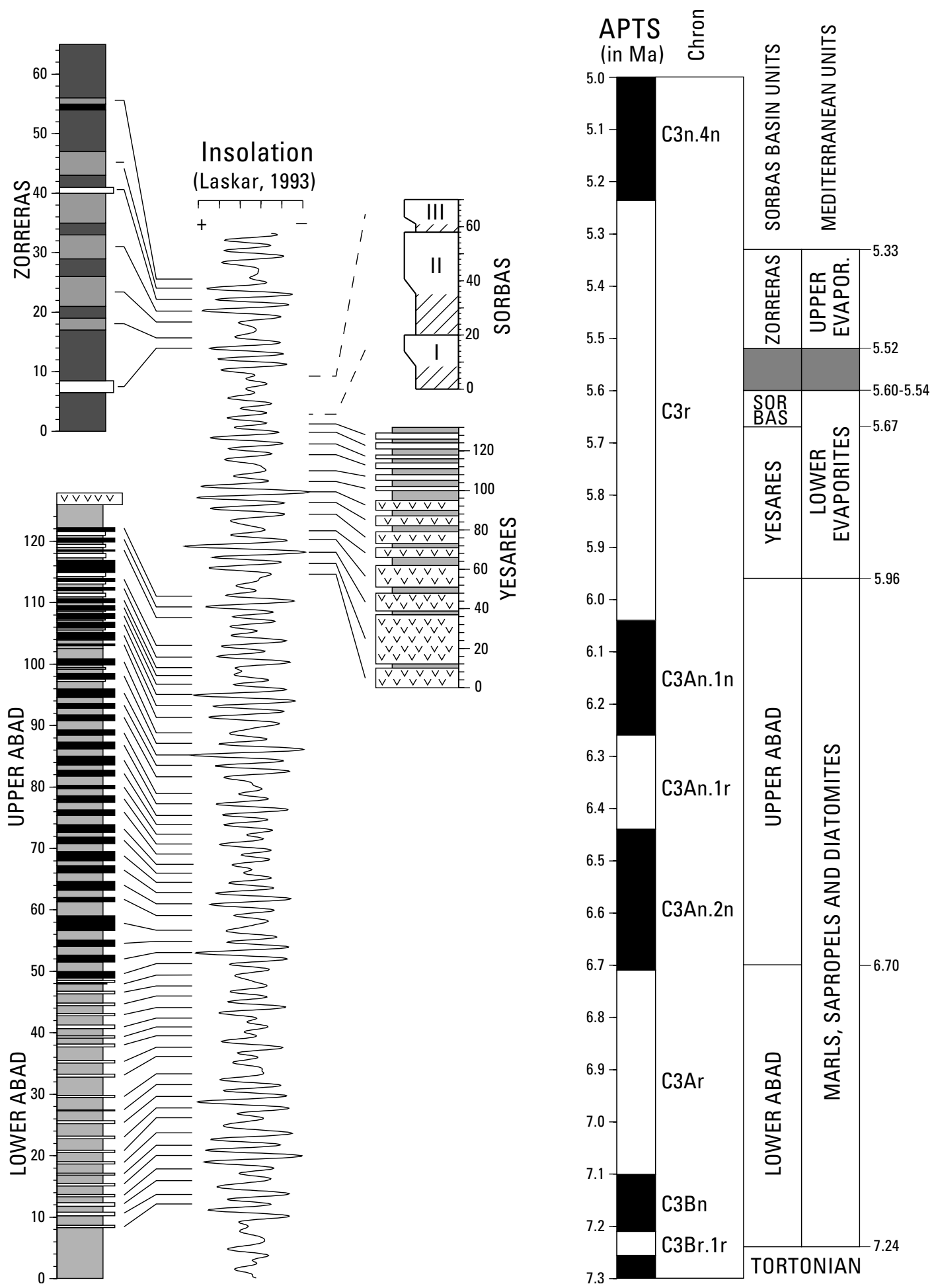
was included in the Zorreras Member may have contributed to confusion in literature concerning its chronostratigraphic position. The yellowish top of the Zorreras Member is followed by reddish PlioPleistocene fluviatile conglomerates of the Góchar Formation.

The cyclicity in the Zorreras Member is expressed as a laterally continuous alternation of reddish continental silty clays and either whitish chalky marls or grey-yellowish sandy marls (Fig. 4). In the type section of the Zorreras Member, the total number of reddish intervals is eight, while seven grey-yellowish intervals are present. Cycle I starts with sandy and silty red-brownish clays, including caliche nodules and a thick parallel laminated sandstone sheet. Eastward, the strongly burrowed oolitic sandstone top of the Sorbas Member is overlain by coarse, purely lithoclastic sandstones. There, the thickness of cycle I has increased with some $2.5 \mathrm{~m}$. Cycle II again starts with reddish silts and sands, but ends with grey clays which have yielded a rodent fauna indicative of a late Miocene age (Martín-Suárez et al., 2000). The higher cycles are characterised by alternations of dominantly clayey, but either reddish, or yellow colours. The top of cycle VII is formed by a black lignitic clay, barren in pollen. In our section, only the reddish interval of cycle VIII is present, although laterally yellowish clays are observed directly below the overlying Pliocene fossiliferous calcarenites. The reddish levels are considered to represent drier periods, while the grey to yellowish units (which ultimately may become lagoonal marly chalks) are interpreted as deposited during wetter periods. During these wetter cycles the basin was twice (cycles I and V) flooded by brackish waters, turning the basin into a lake.

\section{Astrochronology for the Sorbas basin}

Cyclostratigraphic correlation of the sedimentary cycle patterns in the Abad marls to the astronomical curves shows a good to excellent fit (Krijgsman et al., 1999a). The resulting astrochronological age for the base of the Abad Member (T/M boundary) is 7.24 Ma, while the 'Lower/Upper Abad' transition arrives at 6.70 Ma and the Abad/Yesares transition at $5.96 \mathrm{Ma}$ (Fig. 5).

Field evidence from the Vena del Gesso basin of northern Italy reveals that pre-evaporitic marl/ sapropel cycles pass upward via carbonate/sapropel cycles into gypsum/sapropel cycles (Krijgsman et al., 1999b). This indicates that the different types of sedimentary cycles are all related to the same underlying mechanism, namely dominantly precession controlled 'dry-wet' oscillations in (circum)Mediterranean climate. As a consequence, carbonate and gypsum beds have been deposited at times of precession maxima and insolation minima, i.e. during relatively dry periods when evaporation exceeded precipitation (Krijgsman et al., 1999a). The presence of exactly the same type of evaporite cyclicity in the Sorbas basin indicates that the Yesares gypsum cycles are also dominantly precession controlled. An alternative (glacio-eustatic) obliquity control for these gypsum cycles can be excluded on the basis of the total number (25) of sedimentary cycles with a reversed polarity in the Yesares, Sorbas and Zorreras Members.

In the Vena del Gesso basin, the first evaporite bed is observed four sedimentary cycles above the paleomagnetic reversal C3An.ln(y), a level that corresponds to increasing amplitude in the insolation

Fig. 5. Astronomical calibration of the sedimentary cycles of the Messinian Sorbas basin to the insolation curve of Laskar et al. (1993). Astronomical polarity time scale (APTS) is after Hilgen et al. (1995) supplemented by new data on the ages of chron C3An by Krijgsman et al. (1999a). Numbers at the right are astronomical ages (in Ma) of the different members and events. Sedimentary cyclicity in the 'Lower Abad' marls is characterised by an alternation of homogeneous marls (shaded) and Opal CT-rich beds (white), in the 'Upper Abad' marls by alternations of homogeneous marls (shaded) and sapropels (black) with irregularily intercalated diatomites (white) in the upper part. The tning of the Abad marls is consistent with the astrochronology of Hilgen et al. (1995) for older intervals and is explained in more detail by Krijgsman et al. (1999a) and Sierro et al. (2001). The 14 evaporite beds of the Yesares Member correlate to minima in insolation. Note that the lowermost eight gypsum cycles correspond to relatively high amplitudes in insolation, while the uppermost six evaporitic limestones correspond to lower amplitudes. The astronomical tuning of the Sorbas Member is less unambiguous because of unfavourable depositional environment (Coastal sequences) for orbital forcing and several very low amplitude peaks in the insolation record (related to eccentricity minima). The calibration of the Zorreras Member is based on the assumption that the two conspicuous lacustrine (white) intervals (cycles I and $\mathrm{V}$ in Fig. 4) correlate to high amplitude peaks of insolation maxima. The reddish silts (dark shaded) correlate to insolation minima, the yellowish sandy marls (light shaded) to insolation maxima. 
curve (Krijgsman et al., 1999a,b). Based on a constant sedimentation rate, we expect two or three additional sedimentary cycles in the transitional interval to the evaporites of the Sorbas basin. Hence, we assume that the base of the Yesares evaporites corresponds to the amplitude increase in insolation as well. Upward calibration of the fourteen Yesares cycles shows that the eight lowermost thick evaporite beds correlate with relatively high insolation peaks, while the six uppermost thinner beds correlate to less prominent insolation peaks. Our best age estimate for the top of the Yesares Member is $5.67 \mathrm{Ma}$.

The recognition of sedimentary cycles in the Sorbas Member is less straightforward than in the Yesares, but detailed sedimentological investigations revealed the presence of three coastal sequences (Roep et al., 1998). If we interpret these sequences in terms of astronomical forcing, it is tempting to link them to precession as well. However, an obliquity forcing cannot be excluded here because the Sorbas Member was deposited during an interval of low amplitude variations and precession/obliquity interference patterns in insolation, related to the $\sim 400 \mathrm{kyr}$ eccentricity minimum around 5.6 Ma (Fig. 5). As a consequence, the top of the Sorbas Member would either arrive at 5.60 in case of a precessional forcing, or at 5.54 in case of an obliquity control.

The sedimentary cyclicity in the Zorreras Member, expressed as an alternation of reddish silty clays and grey-yellowish sandy marls, is similar to the sedimentary cyclicity observed in other continental (red-bed) sequences of Central Spain, which was earlier shown to be related to precession induced changes in climate (Krijgsman et al., 1997b; Abdul Aziz et al., 2000). Therefore, we interpret the eight sedimentary cycles of the Zorreras Member to be precession controlled as well, resulting in a total duration of approximately $175 \mathrm{kyr}$ for this continental unit. The Zorreras Member is most likely of latest Messinian age (Lago Mare interval), as indicated by the presence of caspibrackish ostracods and the absence of a major hiatus at the Sorbas/Zorreras transition. It cannot be excluded, however, that the top of the Zorreras Member extends into the Pliocene, as the base of the normal Thvera (C3n.4n) subchron is located in the fifth sedimentary cycle above the Mio-Pliocene boundary (Langereis and Hilgen, 1991). We have established a tentative correlation of the Zorreras cycles to the isolation curve (Fig. 5), assuming that the two conspicuous white lacustrine intervals (cycles I and V) correlate to high insolation maxima peaks (i.e. wettest conditions) and that the entire Zorreras belongs to the Messinian.

Our preferred astronomical calibration of all sedimentary cycles (Fig. 5) reveals that only $35 \mathrm{kyr}$ (i.e. two cycles) are missing in the total stratigraphic record if the cycles of the Sorbas Member are obliquity controlled, and $95 \mathrm{kyr}$ (i.e. five cycles) in case of a precessional control. This can easily be explained by small errors in the recognition of the number of cycles especially around lithological transitions, by minor misfits with the astronomical curve, and by the possible existence of minor hiatuses at the Sorbas/Zorreras transition and/or at the base of the Pliocene top part of the Zorreras.

\section{Discussion}

\subsection{Abad member (7.24-5.95 Ma)}

The transition from the shallow marine calcarenites of the Azagador Member to the open marine marls of the 'Lower Abad Member' reflects a rapid deepening of the Sorbas basin approximately at the T/M boundary (7.24 Ma). Estimated paleodepths for the 'Lower Abad', based on planktic and benthic foraminiferal assemblages, range between 200 and $300 \mathrm{~m}$ (Troelstra et al., 1980). Tectonic activity must have caused this transgression because the isotopic signal from the open ocean does not show a significant eustatic sea level rise in the same time interval (Hodell et al., 1994). This tectonic phase is accompanied in southeast Spain by a clockwise rotation of the stress field of approximately 40 degrees during the latest Tortonian (Stapel et al., 1996). Before, major east-west trending faults, related to dextral strike-slip movements, influenced the geometry of the basin margin, while afterwards tectonic displacement mainly took place as sinistral strike-slip movements along NE/SW trending faults parallel to the Palomares fault zone (Fig. 1). In addition, volcanic activity occurred, as a consequence of strike-slip movements along these NE-SW trending faults (Montenat et al., 1975).

Important tectonic activity at the $\mathrm{T} / \mathrm{M}$ boundary interval is also documented in other west 
Mediterranean basins. The basins that were part of the Betic Corridor (the marine connection through Spain between the Mediterranean and Atlantic in pre-Messinian times) have been uplifted at approximately the Tortonian/Messinian boundary and generally show a transition of marine to continental facies (RodríquezFernández et al., 1984; Rodríquez-Fernández and Sanz de Galdeano, 1992; Weijermars, 1988; Garcés et al., 1998; Soria et al., 1999). This strongly indicates that the Betic Corridor became progressively closed during the latest Tortonian/earliest Messinian. Also in the Rifian Corridor, the marine gateway through Morocco, tectonic uplift occurred slightly after the T/M boundary (Krijgsman et al., 1999c), as evidenced by paleobathymetric data from the southern margin (Taza-Guercif basin). These tectonic processes evidently caused a restriction of the MediterraneanAtlantic water exchange and resulted in an important current reversal in the Rifian Corridor (Benson et al., 1991) and the disappearance of several deep-water benthic foraminiferal species in the Mediterranean (Kouwenhoven et al., 1999).

The most conspicuous event during pre-evaporite deposition is the transition at $6.70 \mathrm{Ma}$, from the grey coloured marls of the 'Lower Abad' to the brownish ('tobacco coloured') marls, sapropels and diatomites of the 'Upper Abad Member'. This transition is characterised by a distinct break in the benthic fauna record toward species indicative of more restricted bottom water conditions (Troelstra et al., 1980; Sierro et al., 1999).

Time-equivalent paleoceanographic changes are recorded on Crete, where marl/sapropel alternations are replaced by carbonates associated with reduced terrigenous supply, referred to as the Early Messinian Starvation Event (Santarelli et al., 1998), and on Gavdos where similar marl/sapropel alternations show a gradual transition to diatomite bearing alternations (Krijgsman et al., 1999a). The exact cause for these Mediterranean wide changes are at present still unknown, although a relation with deteriorating Atlantic-Mediterranean connections is suggested (Santarelli et al., 1998). In contrast, the onset of diatomites on Sicily (Tripoli Formation) pre-dates this early Messinian event by approximately $300 \mathrm{kyr}$ (Hilgen and Krijgsman, 1999).

During deposition of the 'Upper Abad' marls a general shallowing of the Sorbas basin of about
$100-150 \mathrm{~m}$ was calculated, based on basin geometry, reef geometry, litho- and bio-facies development, sediment thickness, tectonics and compaction (Troelstra et al., 1980; Dronkert, 1985; Martín et al., 1997). The paleobathymetry of the Sorbas basin at the Abad/ Yesares transition has various estimates: less than $200 \mathrm{~m}$ (Dronkert, 1976, based on basin geometry), between 100 and $150 \mathrm{~m}$ (Troelstra et al., 1980, based on P/B ratios from the 'Upper Abad'), and between 10 and $70 \mathrm{~m}$ (Pagnier, 1976, based on regional distribution of sediments and sedimentary structures). This relative sea-level fall caused erosion and karstification in the fringing reefs at the margins of the Sorbas basin (Martín et al., 1997; Riding et al., 1998).

\subsection{Yesares and Sorbas members (5.95-5.60 Ma): onset of MSC}

The astronomical calibration of the sedimentary cycles of the Abad Member indicates that the transition towards the Yesares evaporites took place at an age of 5.96 Ma, approximately four cycles above the paleomagnetic reversal C3An.ln (y). This is in agreement with the magnetostratigraphic data obtained by Gautier et al. (1994) and with data from the Vena del Gesso basin in the Northern Apennines of Italy (Krijgsman et al., 1999b). In addition, high-resolution cyclostratigraphic and biostratigraphic studies show that the transition from marls to evaporitic limestones (Decima et al., 1988) in the Falconara and Capodarso sections on Sicily (Italy) and in the Metochia section on Gavdos (Greece) - although the evaporitic nature of the carbonates from Gavdos still needs to be demonstrated - occur at exactly the same sedimentary cycle as the Abad/Yesares transition in the sections of the Sorbas and Nijar basins (Hilgen and Krijgsman, 1999; Krijgsman et al., 1999a). This indicates that the onset of the Messinian salinity crisis is a perfectly synchronous event in all the studied basins in both the western and eastern Mediterranean.

The total number of sedimentary cycles in the Yesares and Sorbas Member is estimated at 17. This is in good agreement with the 16 cycles reported from the Gessoso-Solfifera evaporites of the Northern Apennines (Vai and Ricci Lucchi, 1976; Marabini and Vai, 1988) and 16 cycles in the 'Lower Evaporites' of Sicily (Schreiber, personal communication), suggesting that the Yesares Member correlates with 
the 'Lower Evaporites' and not to the 'Upper Evaporites'. In Italy, the transition from 'Lower to Upper Evaporites' marks the main desiccation event and the subsequent reflooding of the Mediterranean with brackish waters. This transition has now been dated astronomically between 5.60 and $5.50 \mathrm{Ma}$, in good agreement with Ar/Ar ages of $5.40 \pm 0.06$ and $5.51 \pm$ 0.05 on volcanic ash layers from the Northern Apennines (Odin et al., 1997).

The correlation of the Yesares and Sorbas Member to a post-MSC reflooding phase of the Mediterranean, as proposed by Martín et al. (1997) and Riding et al. (1998), is thus not tenable because there is clearly not enough time to deposit the 25 sedimentary cycles of reversed polarity (14 Yesares +3 Sorbas +8 Zorreras $= \pm 540 \mathrm{kyr}$ ) between the top of the 'Lower Evaporites' and the base of the Thvera subchron, an interval of maximum $370 \mathrm{kyr}$. Another problem is that in this scenario an explanation must be found why the marine Yesares and Sorbas sediments are deposited in a marginal basin like Sorbas, while the Mediterranean at the same time formed a large Lago Mare basin of predominantly brackish water fauna (McCulloch and De Deckker, 1989). The correlation of Martín et al. (1997) and Riding et al. (1998) is entirely based on the assumption that the Abad/Yesares transition is an erosional surface (representing a hiatus of more than $300 \mathrm{kyr}$ ), during which the top of the Abad Member must have been affected by vigorous erosion. In our opinion the interpretation of this erosional unconformity is not supported by outcrop data. Local unconformities between the Abad and Yesares Members are observed at several outcrops, but these are related to gravitational sliding of the relatively competent gypsum over the underlying marls along Yesares cuesta's. Riding et al. (1998) especially refer to an angular unconformity in the Molinos de Rio de Aguas section, but in the undisturbed cliff outcrops just $\mathrm{W}$ of this section the contacts are conformable. Moreover, if deep erosion had removed much of the Abad Member, then it would have been impossible to retrieve the same uppermost Abad cycles in various adjacent localities. Erosional surfaces are indeed found along the basin margins, such as the distinct unconformity separating the clinoforms from the TCC unit. Towards the basin this surface is hard to trace because evaporite dissolution processes tend to interfere, but it certainly does not extend to the basin centre.

\subsection{Zorreras member (5.5-5.3 Ma): major down- drop of the Mediterranean}

The reversed magnetic polarities of the eight precessional Zorreras cycles indicate that the Zorreras Member is most likely of late Messinian age and that it can be correlated to the 'Upper Evaporites' of Sicily and the Colombacci Formation of Northern Italy. These units also comprise seven to eight sedimentary cycles of reversed polarity (Colalongo et al., 1976; Decima and Wezel, 1973; Rouchy, 1976), suggesting that they are deposited in the same time-interval, bounded by Mediterranean-wide events. We interpret these events to be the desiccation and marine re-flooding of the Mediterranean. Furthermore, every unit contains so-called Lago Mare fauna consisting of caspibrackish ostracod species. Strontium isotopes of ostracod valves indicated that during Zorreras deposition, the Sorbas basin was isolated from the Mediterranean which was in that period a large Lago Mare (Lake Sea) (McCulloch and De Deckker, 1989). This isolation may well have been the result of isostatic rebound processes which are suggested to have occurred predominantly at the Mediterranean margins (Norman and Chase, 1983) when the sea level dropped drastically at the end of the Yesares Member. These uplift processes probably overprinted the overall pattern of late Cenozoic uplift of the entire region (Cloetingh et al., 1991) and restricted the Sorbas basin from the Mediterranean. We suggest that the restricted position of the Sorbas basin prevented it from extensive erosion during the drawdown of the Mediterranean and favoured the deposition of the continental Zorreras sediments.

\section{Conclusions}

The Messinian deposits of the central part of the Sorbas basin all display a distinct sedimentary cyclicity. The cyclicity of the pre-evaporitic Abad Member consists of an alternation of homogeneous marls and sapropels, and is unambiguously shown to be related to the orbital cycle of precession. These marl/sapropel cycles pass upward into the gypsum/sapropel cycles of the Yesares Member indicating that evaporite 
cyclicity is related to the same underlying mechanism, namely a precessional forcing. As a consequence, gypsum beds have been deposited at times of precession maxima and insolation minima, i.e. during relatively dry periods when evaporation exceeded precipitation. A precessional forcing for the three coastal sequences of the Sorbas Member is less straightforward and an obliquity forcing cannot be excluded here. The Zorreras Member consists of eight sedimentary cycles, expressed as alternations of reddish silty clays and grey-yellow sandy marls, which are most likely related to precession as well.

The well-developed sedimentary cyclicity in the Messinian deposits of the Sorbas basin is thus dominantly related to precession controlled dry-wet oscillations in (circum)-Mediterranean climate. This allows a correlation of these deposits to the astronomical curves, resulting in an accurate astrochronological framework for the Sorbas basin. This framework will form a solid basis for high-resolution correlations to marginal carbonate facies and to the Central Mediterranean Messinian event stratigraphy. Furthermore, the most important lithological transitions in the central part of the Sorbas basin are now astronomically dated:

1. The base of the Abad marls, representing a rapid deepening of the Sorbas basin, has an age of 7.24 Ma. During this time interval, tectonic activity along NE-SW striking faults played an important role in the western Mediterranean.

2. The 'Lower/Upper Abad' transition at $6.70 \mathrm{Ma}$ is clearly reflected by an abrupt change in lithology from grey marls with opal-rich layers to brownish coloured marls, sapropels and diatomites. Furthermore, it is characterised by a period of increased gravitational sliding. This event is remarkably synchronous with important paleoceanographic changes in the eastern Mediterranean: onset of diatomites on Gavdos; sediment starvation on Crete, but $300 \mathrm{kyr}$ later than the change from marls to diatomites (Tripoli Formation) on Sicily:

3. The base of the Yesares evaporites at 5.96 Ma is time-equivalent with the onset of evaporites or evaporitic limestones in Northern Italy, Sicily, and Greece (Gavdos). This proves that the Messinian salinity crisis is a perfectly synchronous event in all the studied basins of the western and eastern Mediterranean.

4. The coastal sequences of the Sorbas Member characterise the latest marine sediments of the Sorbas basin. Marine sedimentation in the Sorbas basin ended between 5.60 and $5.54 \mathrm{Ma}$, when the Mediterranean became completely isolated from the Atlantic.

5. The desiccation phase of the Mediterranean took place between the Sorbas and Zorreras Member at 5.6-5.5 Ma. This probably resulted in isostatic uplift of the Mediterranean margins, isolating the Sorbas basin from the adjacent basins and the Mediterranean, thus creating accumulation space for the continental Zorreras sediments.

\section{Acknowledgements}

In the course of the investigations our companion and friend Thomas B. Roep suddenly died. We gratefully acknowledge his participation in the fieldwork, enabling us to share his thorough knowledge of the Sorbas basin. We thank Cor Langereis for various discussions and A. Robertson, G.B. Vai, J.M. Rouchy, C. Taberner for their criticital reviews of the manuscript. Henk Meijer assisted with the paleomagnetic measurements. This study was partly supported by The Netherlands Geosciences Foundation (GOA) with financial aid from the Netherlands Organisation of Scientific Research (NWO) and was conducted under the programme of the Dutch national research schools, the Vening Meinesz Research School of Geodynamics (VMSG) and the Netherlands Research School of Sedimentary Geology (NSG). Funding of FJS was by project DGCYT PB 95-0927 and Fundacion Areces.

\section{References}

Abdul Aziz, H., Hilgen, F.J., Krijgsman, W., Sanz, E., Calvo, J.P., 2000. Astronomical forcing of sedimentary cycles in the Miocene continental Calatayud Basin (NE Spain). Earth Planet. Sci. Lett. 177, 9-22.

Benson, R.H., Rakic-El Bied, K., Bonaduce, G., 1991. An important current reversal (influx) in the Rifian corridor (Morocco) at the Tortonian-Messinian boundary: the end of Tethys Ocean. Paleoceanography 6, 164-192. 
Braga, J.C., Martín, J.M., 1996. Geometries of reef advance in response to relative sea-level changes in a Messinian (uppermost Miocene) fringing reef (Cariatiz reef, Sorbas Basin, SE Spain). Sediment. Geol. 107, 61-81.

Cita, M.B., Wright, R.C., Ryan, W.B.F., Longinelli, A., 1978. Messinian paleoenvironments. In: Hsü, K.J. et al. (Ed.), Initial Reports of the Deep Sea Drilling Project, vol. 42, no. 1, pp. 1003-1035.

Cita, M.B., Santambrogio, S., Melillo, B., Rogate, F., 1990. Messinian paleoenvironments: new evidence from the Tyrrhenian Sea (ODP Leg 107). Proc. ODP, Sci Results 107, 211-227.

Clauzon, G., Suc, J.-P., Gautier, F., Berger, A., Loutre, M.-F., 1996. Alternate interpretation of the Messinian salinity crisis: controversy resolved?. Geology 24, 363-366.

Cloetingh, S., van der Beek, P.A., van Rees, D., Roep, Th.B., Biermann, C., Stephenson, R.A., 1991. Flexural interaction and the dynamics of Neogene extensional basin formation in the Alborán-betic region. Geomar. Lett. 12, 66-75.

Colalongo, M.L., Cremonini, G., Farabegoli, E., Sartori, R., Tampieri, R., Tomadin, L., 1976. Paleoenvironmental study of Colombacci Formation in Romagna (Italy): the Cella section. Mem. Soc. Geol. Ital. 16, 197-216.

Cunningham, K.J., Farr, M.R., Rakic-El Bied, K., 1994. Magnetostratigraphic dating of an Upper Miocene shallow marine and continental sedimentary succession in northeastern Morocco. Earth Planet. Sci. Lett. 127, 77-93.

Dabrio, C.J., Polo, M.D., 1995. Oscilaciones eustáticas de alta frecuencia en el Neógeno superior de Sorbas (Almeria, sureste de España). Geogaceta 18, 75-78.

Dabrio, C.J., Martín, J.M., Megías, A.G., 1985. The tectosedimentary evolution of Mio-Pliocene reefs in the Province of Almeria. In: Milá, M.D., Rosell, J. (Eds.), Sixth European Regional Meeting of Sedimentologists, Excursion Guidebook, Lleida, pp. 269-305.

Decima, A., Wezel, F.C., 1973. Osservazioni sulle evaporiti Messiniane della Sicilia centro-meridionale. Riv. Miner. Sicilinana, Ann. 22 (130-134), 172-187.

Decima, A., McKenzie, J.A., Schreiber, B.C., 1988. The origin of evaporitive limestone: an example from the Messinian of Sicily (Italy). J. Sediment. Petrol. 58, 256-272.

Dronkert, H., 1976. Late Miocene evaporites in the Sorbas Basin and adjoining areas. Mem. Soc. Geol. Ital. 16, 341-361.

Dronkert, H., 1985. Evaporite models and sedimentology of Messinian and Recent evaporites. GUA Papers of Geology, Series 1, vol. 24, 283 pp.

Drooger, C.W. (Ed.), 1973. Messinian Events in the Mediterranean Geodynamics Science Report, vol. 7. North Holland, Amsterdam (272 pp.).

Esteban, M., 1979. Significance of the Upper-Miocene coral reefs of the western Mediterranean. Palaeogeogr. Palaeoclimatol. Palaeoecol. 29, 169-188.

Esteban, M., Giner, J., 1977. El arrecife de Santa Pola. In: Salas, R. (Ed.), Primer Seminario Práctico de Asociaciones Arrecifales y Evaporíticas, Barcelona, p. 11S.

Garcés, M., Krijgsman, W., Agustí, J., 1998. Chronology of the late Turolian deposits of the Fortuna basin: implications for the Messinian evolution of the eastern Betics. Earth Planet. Sci. Lett. 163, 69-81.
Gautier, F., Clauzon, G., Suc, J.-P., Cravette, J., Violant, D., 1994. Age et durée de la crise de salinité messinienne. C. R. Acad. Sci. Paris, Sér. 2 318, 1103-1109.

Hilgen, F.J., Krijgsman, W., Langereis, C.G., Lourens, L.J., Santarelli, A., Zachariasse, W.J., 1995. Extending the astronomical (polarity) time scale into the Miocene. Earth Planet Sci. Lett. 136, 495-510.

Hilgen, F.J., Krijgsman, W., 1999. Cyclostratigraphy and astrochronology of the Tripoli diatomite Formation (pre-evaporite Messinian, Sicily, Italy). Terra Nova 11, 16-22.

Hodell, D.A., Benson, R.H., Kent, D.V., Boersma, A., Rakic-El Bied, K., 1994. Magnetostratigraphic, biostratigraphic, and stable isotope stratigraphy of an Upper Miocene drill core from the Salé Briqueterie (northwest Morocco): a high-resolution chronology for the Messinian stage. Paleoceanography 9, $835-855$.

Hsü, K.J., Ryan, W.B.F., Cita, M.B., 1973. Late Miocene desiccation of the Mediterranean. Nature 242, 240-244.

Hsü, K.J., et al., 1977. History of the Messinian salinity crisis. Nature 267, 399-403.

Iaccarino, S., Morlotti, E., Papani, G., Pelosio, G., Raffi, S., 1975. Litostratigrafia e biostratigrafia di alcune serie neogeniche della provincia di Almería (Andalusia orientale-Spagna). Ateneo Parmense, Acta Nat. 11, 237-313.

Krijgsman, W., Hilgen, F.J., Negri, A., Wijbrans, J.R., Zachariasse, W.J., 1997a. The Monte del Casino section (Northern Apennines, Italy): a potential Tortonian-Messinian boundary stratotype. Palaeogeogr. Palaeoclimatol. Palaeoecol. 133, 27-47.

Krijgsman, W., Delahaije, W., Langereis, C.G., De Boer, P.L., 1997b. Cyclicity and NRM acquisition in the Armantes section (Miocene, Spain): Potential for an astronomical polarity time scale for the continental record. Geophys. Res. Lett. 24 (9), 1027-1030.

Krijgsman, W., Hilgen, F.J., Raffi, I., Sierro, F.J., Wilson, D.S., 1999a. Chronology, causes and progression of the Messinian salinity crisis. Nature 400, 655-662.

Krijgsman, W., Hilgen, F.J., Marabini, S., Vai, G.B., 1999b. New paleomagnetic and cyclostratigraphic age constraints on the Messinian of the Northern Apennines (Vena del Gesso Basin, Italy). Mem. Soc. Geol. Ital. 54, 25-33.

Krijgsman, W., Langereis, C.G., Zachariasse, W.J., Boccaletti, M., Moratti, G., Gelati, R., Iaccarino, S., Papani, G., Villa, G., 1999c. Late Neogene evolution of the Taza-Guercif Basin (Rifian Corridor; Morocco) and implications for the Messinian salinity crisis. Mar. Geol. 153, 147-160.

Kouwenhoven, T.J., Seidenkrantz, M.-S., Van der Zwaan, G.J., 1999. Deep-water changes: the near-synchronous disappearance of a group of benthic foraminifera from the late Miocene Mediterranean.Palaeogeogr. Palaeoclimat. Palaeoecol. 152, 259-281.

Langereis, C.G., Hilgen, F.J., 1991. The Rossello composite: a Mediterranean and global reference section for the Early to early Late Pliocene. Earth Planet. Sci. Lett. 104, 211-225.

Laskar, J., Joutel, F., Boudin, F., 1993. Orbital, precessional, and insolation quantities for the Earth from $-20 \mathrm{Myr}$ to $+10 \mathrm{Myr}$. Astron. Astrophys. 270, 522-533.

Marabini, S., Vai, G.B., 1988. Geology of the Monticino Quarry, 
Brisighella, Italy. Stratigraphic implications of its late Messinian fauna. In: D.C. Giuli, G.B. Vai (Eds.), Fossil vertebrates in the Lamone valley, Romagna Apennines. Field trip guidebook, pp. $39-52$.

Martín, J.M., Braga, J.C., 1994. Messinian events in the Sorbas Basin in southeastern Spain and their implications in the recent history of the Mediterranean. Sediment. Geol. 90, 257-268.

Martín, J.M., Braga, J.C., Riding, R., 1993. Siliciclastic stromatolites and thrombolites, late Miocene, SE Spain. J. Sediment. Petrol. 63 (1), 131-139.

Martín, J.M., Braga, J.C., Riding, R., 1997. Late Miocene Halimeda alga-microbal segment reefs in the marginal Mediterranean Sorbas Basin, Spain. Sedimentology 44, 441-456.

Martín-Suárez, E., Freudenthal, M., Krijgsman, W., Fortuin, A.R., 2000. On the age of the continental deposits of the Zorreras Member (Sorbas Basin, SE Spain). Geobios (in press).

McCulloch, M.T., De Deckker, P., 1989. Sr isotope constraints on the Mediterranean environment at the end of the Messinian salinity crisis. Nature $342,62-65$.

Montenat, C., Thaler, L., Van Couvering, J.A., 1975. La faune de rongeurs de Librilla. Correlations avec les formations marines du Miocène terminal et les datations radiometriques du volcanisme de Barqueros (Province de Murcia, Espagne méridional). C. R. Acad. Sci. Paris 281, 519-522.

Montenat, C., Ott d'Estevou, P., de Larouzière, F.D., Bedu, P., 1987. Originalité géodynamique des bassins Néogènes du domaine Bétique oriental (Espagne). Notes Mém. CFP 21, 11-50.

Müller, D.W., Hsü, K.J., 1987. Event stratigraphy and paleoceanography in the Fortuna Basin (Southeast Spain): a scenario for the Messinian Salinity Crisis. Paleoceanography 2 (6), 679-696.

Norman, S.E., Chase, C.G., 1983. Uplift of the shores of the western Mediterranean due to Messinian desiccation and flexural isostasy. Nature 322, 450-451.

Odin, G.S., Ricci Lucchi, F., Tateo, F., Cosca, M., Hunziker, J.C., 1997. Integrated stratigraphy of the Maccarone section, late Messinian (Marche region, Italy). In: Montanari, A., Odin, G.S., Coccioni, R. (Eds.). Miocene Stratigraphy: An Integrated Approach. Elsevier, Amsterdam, pp. 531-545.

Offringa, J.E., 1991. De geologie van het noordoostelijk Sorbas Bekken, Prov. Almería, S.E. Spanje. Unpublished Report, Faculty of Earth Sciences, Vrije Universiteit, Amsterdam, 59 pp.

Ott d'Estevou, Ph., 1980. Evolution dynamique du bassin néogène de Sorbas (Cordillères bétiques orientales, Espagne). Thèse Doc. Trav. IGAL, Paris, vol. 1, 264 pp.

Ott d'Estevou, Ph., Montenat, C., 1990. Le bassin de Sorbas-Tabernas. In: Montenat, C. (Ed.) Les bassins Néogènes du domaine Bétique Oriental (Espagne), tectonique et sedimentation dans un couloir de dechrochement, Pt. 1 Etude Regionale. Doc. Trav. IGAL, Paris, vols. 12-13, pp. 101-128.

Pagnier, H., 1976. Depth of deposition of Messinian selenitic gypsum in the basin of Sorbas (SE Spain). Mem. Soc. Geol. Ital. 16, 363-367.

Riding, R., Braga, J.C., Martín, J.M., Sánchez-Almazo, I.M., 1998. Mediterranean Messinian Salinity Crisis: constraints from a coeval marginal basin, Sorbas, southeastern Spain. Mar. Geol. $146,1-20$.
Rodríguez-Fernández, J., Sanz de Galdeano, C., 1992. Onshore Neogene Stratigraphy in the North of the Alboran Sea (Betic Internal Zones): paleogeographic implications. Geomar. Lett. 12, 123-128.

Rodríguez-Fernández, J., Fernández, J., Lopez Garrido, A.C > , Sanz de Galdeano, C., 1984. The central sector of the Betic Cordilleras, a realm situated between the Atlantic and Mediterranean domains during the upper Miocene. Ann. Géol. Pays. Hell. 32, 97-103.

Roep, Th.B., Beets, D.J., 1977. An excursion to coastal and fluvial sediments of Messinian-Pliocene age (Sorbas member and Zorreras member) in the Sorbas Basin, SE Spain. Messinian Seminar 3, Malaga.

Roep, Th.B., Van Harten, D., 1979. Sedimentological and ostracodological observations on Messinian post-evaporite deposits in some southeastern Spanish basins. Ann. Geol. Pays. Hellén. III, 1037-1044.

Roep, Th.B., Beets, D.J., Dronkert, H., Pagnier, H., 1979. A prograding coastal sequence of wave-built structures of Messinian age, Sorbas, Almería, Spain. Sediment. Geol. 22, 135-163.

Roep, Th.B., Dabrio, C.J., Fortuin, A.R., Polo, M.D., 1998. Late highstand patterns of shifting and stepping coastal barriers and washover-fans (late Messinian, Sorbas Basin, SE Spain). Sediment. Geol. 116, 27-56.

Rosell, L., Ortí, F., Kasprzyk, A., Playà, E., Peryt, T.M., 1998. Strontium geochemistry of Miocene primary gypsum: Messinian of southeastern Spain and Sicily and Badenian of Poland. J. Sediment. Res. 68, 63-79.

Rouchy, J.M., 1976. Sur la genèse des deux principaux types de gypse (finement lié et en chevrons du miocène terminal de Sicile et d'Espagne méridionale. Revue géographie physique et géologie dynamique, XVIII 4, 347-364.

Rouchy, J.M., 1982. La genèse des évaporites messiniennes de Méditerranée. Muséum National d'Histoire Naturelle, Paris, Mémoires, Nouvelle Série, Série C, Sciences de la Terre 50, 1-267.

Ruegg, G.J.H., 1964. Geologische onderzoekingen in het bekken van Sorbas. SE Spanje. Internal Report Geol. Inst. Univ. Amsterdam, 67 pp.

Ryan, W.B.F., et al., 1973. Initial Reports of the DSDP, vol. 13. US Government Printing Office, Washington, DC.

Santarelli, A., Brinkhuis, H., Hilgen, F.J., Lourens, L.J., Versteegh, G.J.M., 1998. Orbital signatures in a late Miocene dinoflagellate record from Crete (Greece). Mar. Micropaleontol. 33, 273-297.

Selli, R., 1960. Il Messiniano Mayer-Eymar (1867). Proposta di un neostratotipo. Giorn. Geol. 28, 1-33.

Sierro, F.J., Flores, J.A., Civis, J., González Delgado, J.A., Francés, G., 1993. Late Miocene globorotaliid event-stratigraphy and biogeography in the NE-Atlantic and Mediterranean. Mar. Micropaleontol. 21, 143-168.

Sierro, F.J., Flores, J.A., Zamarreno, I., Vazquez, A., Utrilla, R., Frances, G., Hilgen, F., Krijgsman, W., 1997. Astronomical cyclicity and sapropels in the pre-evaporitic Messinian of the Sorbas basin (Western Mediterranean). Geogaceta 21, 199-202.

Sierro, F.J., Flores, J.A., Zamarreno, I., Vazquez, A., Utrilla, R., Frances, G., Hilgen, F.J., Krijgsman, W., 1999. Messinian climatic oscillations, astronomic cyclicity and reef growth in the western Mediterranean. Mar. Geol. 153, 137-146. 
Sierro, F.J., Hilgen, F.J., Krijgsman, W., Flores, J.A., 2001. The Abad composite (SE Spain): A Messinian reference section for the Mediterranean and the APTS. Palaeogeogr. Palaeoclimatol. Palaeoecol. (in press).

Soria, J.M., Fernández, J., Viseras, C., 1999. Late Miocene stratigraphy and palaeogeographic evolution of the intramontane Guadix Basin (Central Betic Cordillera, Spain): implications for an Atlantic-Mediterranean connection. Palaeogeogr. Palaeoclimatol. Palaeoecol. 151, 255-266.

Stapel, G., Moeys, R., Biermann, C., 1996. Neogene evolution of the Sorbas basin (SE Spain) determined by paleostress analysis. Tectonophysics 255, 291-305.

Steehouwer, M., Van der Moolen, Ch., 1996. Cyclicities in the Abad Marls of the Sorbas and Nijar basins, South-East Spain: a gamma ray approach. Unpublished Report, Faculty of Earth Sciences, Vrije Universiteit, Amsterdam, 25 pp.

Ten Veen, J., 1991. De geologie van het centrale Sorbas Bekken, SE Spanje. Unpublished Report, Faculty of Earth Sciences, Vrije Universiteit, Amsterdam, 62 pp.

Troelstra, S.R., van de Poel, H.M., Huisman, C.H.A., Geerlings, L.P.A., Dronkert, H., 1980. Paleoecological changes in the latest Miocene of the Sorbas Basin, SE Spain. Geol. Meditt. 7, 115126.
Vai, G.B., Ricci Lucchi, F., 1976. The Vena del Gesso in northern Apennines: growth and mechanical breakdown of gypsified algal crusts. Mem. Soc. Geol. It 16, 217-249.

Van de Poel, H.M., 1994. Messinian marginal-marine and continental facies and their stratigraphy in the eastern Almería Province (SE Spain). Strata, Acta du Lab. de Géologie Sédiment. et Paléontol. de 1'Université Paul Sabatier, Toulouse, Sér., 2, Mém. 23, 202 pp.

Van Harten, D., 1980. On Cyprideis undosa Van Harten, sp. nov. In: Bate, R.H. et al. (Eds.), A Stereo Atlas of Ostracod shells, vol. 7, no. 15 , pp. $81-88$.

Vazquez, A., Utrilla, R., Zamarreno, I., Sierro, F.J., Flores, J.A., Frances, J.A., Barcena, M.A., 2000. Precession related sapropelites of the Messinian Sorbas basin (South Spain): Paleoenvironmental significance. Palaeogeogr. Palaeoclimat. Palaeoecol. (in press).

Völk, H.R., Rondeel, H.E., 1964. Zur gliederung des Jungtertiärs in becken von Vera, Südost Spanien. Geol. Mijnbouw 43, 310-315.

Weijermars, R., 1988. Neogene tectonics in the western Mediterranean may have caused the Messinian salinity crisis and an associated glacial event. Tectonophysics 148, 211-219. 